\title{
Struktur komunitas laba-laba di ekosistem padi ratun: pengaruh aplikasi Beauveria bassiana (Balsamo)
}

\author{
Community structure of spiders in ratoon paddy ecosystem: \\ effect of Beauveria bassiana (Balsamo) application
}

\author{
Siti Herlinda ${ }^{1,2}{ }^{*}$, Rafika Dewi ${ }^{1}$, Triani Adam ${ }^{1}$, Suwandi $^{1,2}$, Andi Wijaya ${ }^{2}$ \\ ${ }^{1}$ Jurusan Hama dan Penyakit Tumbuhan, Fakultas Pertanian, Universitas Sriwijaya \\ Jalan Raya Palembang-Prabumulih, Km 32, Ogan Ilir, Indralaya 30662 \\ ${ }^{2}$ Pusat Unggulan Riset Pengembangan Lahan Suboptimal, Universitas Sriwijaya \\ Jalan Padang Selasa 524, Palembang 30139
}

(diterima Mei 2014, disetujui Februari 2015)

\begin{abstract}
ABSTRAK
Laba-laba merupakan salah satu predator penting dalam mengatur populasi serangga hama di ekosistem padi. Aplikasi cendawan entomopatogen, seperti Beauveria bassiana (Balsamo) diharapkan tidak mempengaruhi keberadaan laba-laba tersebut. Penelitian ini bertujuan untuk mempelajari pengaruh aplikasi bioinsektisida $B$. bassiana terhadap kelimpahan, dan kekayaan spesies laba-laba di ekosistem padi ratun. Penelitian dilakukan pada lahan padi ratun seluas 3 ha dengan tiga perlakuan, yaitu (i) bioinsektisida cair dari B. bassiana dengan dosis 2 1/ha/aplikasi, (ii) ekstrak kompos (tanpa bioinsektisida cair) dengan dosis 2 1/ha/aplikasi, dan (iii) bioinsektisida cair dari B. bassiana dan ekstrak kompos dengan dosis masing-masing 2 1/ha/aplikasi. Hasil penelitian menunjukkan bahwa aplikasi bioinsektisida $B$. bassiana tidak memengaruhi kelimpahan dan kekayaan spesies laba-laba di ekosistem padi ratun. Untuk laba-laba penghuni tajuk, perlakuan yang diterapkan tidak memberikan pengaruh pada kekayaan dan kelimpahan spesies laba-laba. Begitu juga untuk laba-laba penghuni permukaan tanah, perlakuan juga tidak mempengaruhi kekayaan dan kelimpahan spesies laba-laba. Perlakuan yang diberikan juga tidak mempengaruhi perubahan komposisi spesies laba-laba pada tajuk maupun pada permukaan tanah. Berdasarkan hasil yang diperoleh dapat disimpulkan bahwa aplikasi bioinsektisida $B$. bassiana tidak membahayakan laba-laba pada ekosistem padi ratun.
\end{abstract}

Kata kunci: agensia hayati, arthropoda predator, bioinsektisida

\begin{abstract}
Spiders are the main predators in paddy ecosystem. Application of entomopathogenic fungus, such as Beauveria bassiana (Balsamo) is not expected to have any negative effect on spiders in the paddy field. This research was aimed to compare species composition, abundance, and species richness of spiders in ratoon paddy. The research was done on three hectares of rice fields that were treated with the following treatment, (i) $2 \mathrm{~L} /$ ha/application of liquid B. bassiana, (ii) $2 \mathrm{~L} / \mathrm{ha} /$ application compost extract (without liquid B. bassiana), and (iii) a combination of liquid $B$. bassiana and compost extract with each using the same $2 \mathrm{~L} / \mathrm{ha} /$ application dose. The result of this research showed that B. bassiana bioinsecticide application did not affect the abundance and species richness of spiders in ratoon paddy. The treatments did not significantly affect species richness and abundance of the canopy-inhabiting spiders. The species richness and abundance of the soil-dwelling spiders on the paddy field applied by the bioinsecticide was not different from those without the bioinsecticide. The treatments did not effect species composition of the canopy-inhabiting and the soil-dwelling spiders. Application of B. bassiana bioinsecticide was not harmful for the spiders in the rice field.
\end{abstract}

Key words: biocontrol agents, bioinsecticies, predatory arthropods

\footnotetext{
*Penulis korespondensi: Siti Herlinda. Jurusan Hama dan Penyakit Tumbuhan, Fakultas Pertanian, Universitas Sriwijaya, 


\section{PENDAHULUAN}

Padi ratun (ratoon) merupakan padi yang telah dipanen kemudian bertunas hingga berbuah kembali. Padi ratun telah dikembangkan di berbagai lokasi di Indonesia, seperti di daerah pasang surut Sumatera Selatan. Sama halnya dengan padi utama, padi ratun dalam pengembangannya sering mengalami gangguan serangan organisme pengganggu tanaman, seperti serangga hama dan penyakit. Serangga hama yang telah ditemukan menyerang padi ratun, antara lain adalah wereng dan walang sangit.

Untuk meningkatkan produktivitas padi ratun, serangga hama yang menyerangnya perlu dikendalikan dengan cara ramah lingkungan, misalnya dengan melakukan pengendalian hayati yang memanfaatkan agens hayati. Agens hayati yang banyak digunakan untuk mengendalikan berbagai jenis hama adalah Beauveria bassiana (Balsamo) Vuillemin. B. bassiana telah terbukti dapat mengendalikan serangga hama padi utama, seperti walang sangit (Herlinda et al. 2008a), wereng (Herlinda et al. 2008b), dan penggerek batang padi (Thalib et al. 2013).

Penelitian tentang dampak aplikasi cendawan entomopatogen telah banyak dilakukan oleh peneliti sebelumnya, misalnya dampak penggunaan $B$. bassiana terhadap serangga predator, Chrysoperla carnea (Stephens) dan Harmonia axyridis (Pallas) (Zhu et al. 2011), Coccinella septempunctata Linnaeus (Thungrabeab \& Tongma 2007), dan Orius insidiosus (Say) (Ludwig \& Oetting 2001). Hasil penelitian tersebut cenderung menyimpulkan hal yang sama, yaitu $B$. bassiana tidak berdampak buruk terhadap arthropoda predator.

Di ekosistem padi, laba-laba yang umumnya ditemukan adalah Pardosa pseudoannulata (Bösenberg \& Strand) dan P. birmanica (Simon) (Herlinda et al. 2004; Khodijah et al. 2012). Labalaba tersebut merupakan predator penting pemangsa wereng, penggerek batang, dan hama lainnya. Munyuli (2009) menyatakan bahwa labalaba merupakan predator penting dalam mengatur populasi serangga hama. Aplikasi cendawan entomopatogen, seperti B. bassiana diharapkan tidak mengganggu keberadaan laba-laba tersebut. Penelitian ini bertujuan untuk mempelajari pengaruh aplikasi $B$. bassiana terhadap kelimpahan, dan kekayaan spesies di ekosistem padi ratun.

\section{BAHAN DAN METODE}

\section{Lokasi penelitian}

Penelitian ini dilaksanakan di sentra sawah pasang surut di Desa Mulia Sari, Kabupaten Banyuasin, Sumatera Selatan mulai bulan Maret sampai Juli 2013. Luas lahan yang digunakan adalah 3 ha dengan sistem budi daya ratun.

\section{Desain penelitian dan perlakuan}

Lahan padi dibagi menjadi tiga petak untuk diberikan perlakukan dengan setiap petak terdiri atas empat subpetak sebagai ulangan. Adapun perlakuan yang diberikan adalah (i) bioinsektisida cair dari $B$. bassiana dengan dosis $21 /$ ha/aplikasi, (ii) ekstrak kompos (tanpa bioinsektisida cair) dengan dosis 2 1/ha/aplikasi, dan (iii) bioinsektisida cair dari B. bassiana dan ekstrak kompos dengan dosis masing-masing 2 1/ha/aplikasi.

\section{Aplikasi bioinsektisida}

Bioinsektisida cair dibuat dari B. bassiana sebagai bahan aktifnya, sedangkan bahan pembawanya berupa kompos cair. Metode pembuatan bioinsektisida ini menggunakan metode yang dilakukan oleh Herlinda et al. (2012), sedangkan pembuatan kompos cair mengikuti metode yang digunakan oleh Suwandi (2004). Bioinsektisida dan kompos cair tersebut diaplikasikan pada tajuk tanaman padi di sore hari setiap minggu, mulai saat padi ratun berumur 14, 21, 28, dan 35 hari.

\section{Pengamatan laba-laba penghuni tajuk}

Pengambilan contoh laba-laba penghuni tajuk dilakukan menggunakan jaring dengan ayunan ganda. Jaring diayunkan pada tajuk tanaman padi sebanyak 60 ayunan ganda untuk 4 ulangan. Pengambilan contoh laba-laba penghuni tajuk ini dilakukan setiap minggu mulai saat padi ratun berumur 3 (sebelum aplikasi bioinsektisida), 17, 31, 38,45 , dan 52 hari umur ratun, serta 14 hari setelah padi ratun dipanen. Bersamaan waktu dengan pengambilan contoh laba-laba tanah dilakukan pengambilan contoh laba-laba penghuni tajuk. Labalaba dari jaring selanjutnya dibersihkan dari kotoran lainnya, kemudian diambil artropodanya, dan dimasukkan ke dalam botol yang berisi alkohol 70\%.

\section{Pengamatan laba-laba penghuni permukaan tanah}

Pengambilan contoh laba-laba penghuni permukaan tanah dilakukan menggunakan perangkap 
lubang (pitfall trap). Perangkap lubang dipasang di permukaan tanah sebanyak 12 perangkap lubang untuk 4 ulangan. Pemasangan perangkap lubang ini dilakukan saat padi ratun berumur 3 (sebelum aplikasi bioinsektisida), 17, 31, 38, 45, dan 52 hari umur ratun, serta 14 hari setelah padi ratun dipanen. Bersamaan waktu dengan pengambilan contoh laba-laba tanah dilakukan pengambilan contoh laba-laba penghuni tajuk. Laba-laba dari perangkap lubang tersebut, selanjutnya dibersihkan dari kotoran lainnya, diambil artropodanya, lalu dimasukkan ke dalam botol yang berisi alkohol $70 \%$.

\section{Identifikasi laba-laba}

Identifikasi laba-laba dilakukan di Laboratorium Entomologi, Jurusan Hama dan Penyakit Tumbuhan, Fakultas Pertanian, Universitas Sriwijaya. Identifikasi laba-laba dilakukan dengan menggunakan kunci identifikasi yang tersedia seperti Barrion \& Litsinger (1995) dan Shepard et al. (1991).

\section{Analisis data}

Keanekaragaman spesies laba-laba pada ekosistem padi ratun dianalisis dengan menggunakan indeks keanekaragaman spesies Shannon-Wienner, indeks dominasi dan kemerataan mengikuti metode Magurran (1987). Perbedaan jumlah spesies dan individu laba-laba antar perlakuan dianalisis dengan menggunakan analisis ragam (ANOVA). Perbedaan komposisi spesies dianalisis menggunakan analisis kemiripan (ANOSIM). Penghitungan dalam analisis data ini dibantu oleh Program SAS-STAT.

\section{HASIL}

Total spesies laba-laba penghuni tajuk yang ditemukan pada ketiga petak perlakuan adalah 18 spesies (Tabel 1). Famili laba-laba penghuni tajuk yang dominan ditemukan adalah Lycosidae, Araneidae, Tetragnathidae, dan Oxyopidae. Dua spesies yang dominan ditemukan pada tajuk tanaman padi ratun pada penelitian ini adalah $P$. pseudoannulata dan Oxyopes javanus.

Total semua spesies laba-laba penghuni permukaan tanah yang ditemukan pada ketiga petak perlakuan hanya 7 spesies (Tabel 2). Famili labalaba penghuni permukaan tanah yang dominan

Tabel 1. Spesies laba-laba yang ditemukan di tajuk padi ratun yang diaplikasikan bioinsektisida cair, kompos cair, dan kombinasi bioinsektisida cair dan kompos cair

\begin{tabular}{|c|c|c|c|}
\hline \multirow{2}{*}{ Spesies dan famili } & \multicolumn{3}{|c|}{ Bioinsektisida } \\
\hline & Bioinsektisida cair & Kompos & Bioinsektisida cair + Kompos \\
\hline \multicolumn{4}{|l|}{ Lycosidae } \\
\hline Pardosa pseudoannulata & + & + & + \\
\hline P. birmanica & + & + & + \\
\hline P. mackenziei & + & & \\
\hline P. warayensis & + & + & + \\
\hline \multicolumn{4}{|l|}{ Araneidae } \\
\hline Araneus inustus & + & + & + \\
\hline Neoscona theisi & + & + & + \\
\hline N. seylla & & + & \\
\hline Larinia sp. & + & + & + \\
\hline Agriope catenulata & + & & \\
\hline \multicolumn{4}{|l|}{ Tetragnathidae } \\
\hline Tetragnatha javana & + & + & + \\
\hline T. virescens & + & + & + \\
\hline T. iwahigensis & + & & \\
\hline T. ilavaca & + & & \\
\hline T. mandibulata & & & + \\
\hline Dyschiriognatha javana & + & + & \\
\hline D. hawigtenera & & + & \\
\hline \multicolumn{4}{|l|}{ Oxyopidae } \\
\hline Oxyopes javanus & + & + & + \\
\hline \multicolumn{4}{|l|}{ Clubionidae } \\
\hline Clubiona japonicola & & + & + \\
\hline Total & 14 & 13 & 11 \\
\hline
\end{tabular}


ditemukan hanya Lycosidae, sedangkan spesies yang dominan ditemukan pada permukaan tanah hanya P. pseudoannulata.

Bila dibandingkan dengan antara petak perlakuan, proporsi spesies laba-laba penghuni tajuk di petak yang diaplikasi kombinasi bioinsektisida cair dan kompos ialah paling sedikit (29\%) sedangkan pada petak yang diaplikasi kompos atau bioinsektisida cair proporsinya masing-masing $34 \%$ dan 37\% (Gambar 1A). Untuk laba-laba permukaan tanah pada petak yang diaplikasi kompos, proporsi jumlah spesiesnya paling kecil (30\%) dibandingkan dengan perlakuan lainnya(Gambar 1B). Berdasarkan hasil analisis menunjukkan bahwa perlakuan yang diterapkan tidak memberikan pengaruh pada kekayaan $\left(\mathrm{F}_{2,9}=2,714, \mathrm{P}=0,120\right)$ dan kelimpahan spesies $\left(\mathrm{F}_{2.9}=0,728, \mathrm{P}=0,509\right)$ laba-laba penghuni tajuk. Perlakuan juga tidak memengaruhi kekayaan $\left(\mathrm{F}_{2,9}=0,280, \mathrm{P}=0,601\right)$ dan kelimpahan spesies $\left(\mathrm{F}_{2,9}\right.$ $=0,728, \mathrm{P}=0,762$ ) laba-laba penghuni permukaan tanah.
Hasil penelitian juga menunjukkan bahwa perlakuan yang diberikan juga tidak memengaruhi keanekaragaman laba-laba pada umur padi ratun yang berbeda. Di setiap perlakuan, yaitu saat awal pertumbuhan ratun hingga ratun berumur 45 hari jumlah individu laba-laba lebih tinggi, dan saat umur ratun 52 hari hingga setelah dipanen jumlah individu terus menurun (Tabel 3). Jumlah individu laba-laba di tajuk paling banyak ditemukan pada perlakuan bioinsektisida cair (37\%), diikuti oleh kombinasi bioinsektisida cair dan kompos (33\%) sedangkan terendah ditemukan pada perlakuan kompos (30\%) (Gambar 2A).

Keanekaragaman spesies laba-laba penghuni tajuk untuk semua perlakuan cenderung tinggi pada awal pertumbuhan ratun hingga ratun berumur 45 hari dan setelah itu terus menurun. Keanekaragaman spesies laba-laba yang ditemukan di permukaan tanah hanya tinggi saat ratun berumur 3 hari, setelah itu keanekaragaman spesies turun drastis. Selama satu musim tanam ratun,

Tabel 2. Spesies laba-laba yang ditemukan di permukaan tanah di ekosistem padi ratun yang diaplikasikan bioinsektisida cair, kompos cair, dan kombinasi bioinsektisida cair dan kompos cair

\begin{tabular}{lccc}
\hline \multirow{2}{*}{ Spesies dan famili } & \multicolumn{3}{c}{ Bioinsektisida } \\
\cline { 2 - 4 } & Bioinsektisida cair & Kompos & Bioinsektisida cair + Kompos \\
\hline Lycosidae & + & + & + \\
$\quad$ Pardosa pseudoannulata & + & + & + \\
P. sumatrana & + & + & + \\
P. birmanica & + & + & + \\
Trochosa sp. & + & & + \\
Arctosa tanakai & & + & + \\
Araneidae & + & & + \\
Neoscona nautica & & & + \\
$\quad$ Araneus inustus & & & + \\
Theridiidae & + & 6 & + \\
$\quad$ Xysticus sp. & 7 & & + \\
\hline Total & & & \\
\hline
\end{tabular}

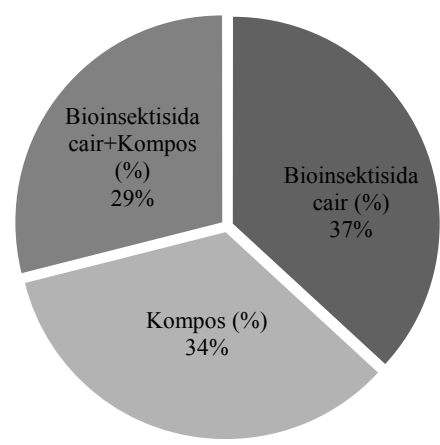

A

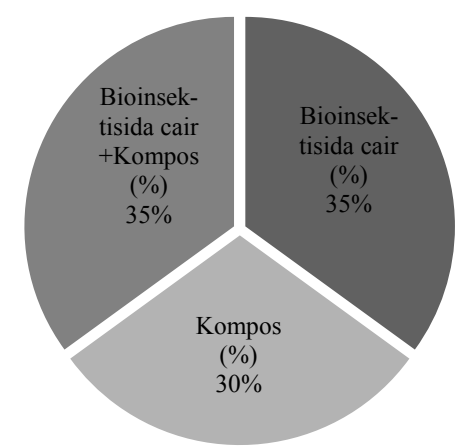

Gambar 1. Komposisi jumlah spesies laba-laba pada tiga petak perlakuan bioinsektisida untuk penguhi tajuk (A) maupun permukaan tanah (B). 
keanekaragaman spesies laba-laba penguni tajuk cenderung lebih tinggi dibandingkan dengan labalaba yang ditemukan di permukaan tanah (Tabel 3 dan 4).

Kemiripan komposisi laba-laba tajuk paling tinggi ditemukan pada petak yang diaplikasikan bioinsektisida cair + kompos dan kompos $(0,83)$ sedangkan untuk predator penghuni permukaan tanah kemiripan spesies cukup tinggi ditemukan antara petak yang diaplikasikan bioinsektisida cair dan kompos $(0,77)$, kemiripan yang sama juga ditemukan pada petak yang diaplikasikan bioinsektisida cair + kompos dan kompos $(0,77)$ (Tabel 5). Berdasarkan ANOSIM menunjukkan bahwa perlakuan bioinsektisida cair dan kombinasinya tidak mempengaruhi komposisi spesies laba-laba pada tajuk (ANOSIM $\mathrm{R}=0,133, \mathrm{P}=$ 0,153 ) dan permukaan tanah (ANOSIM $\mathrm{R}=$ $0,0011, \mathrm{P}=0,410$ ).

Selama satu musim tanam padi ratun, labalaba yang ditemukan di permukaan tanah juga menunjukkan kecenderungan yang sama di setiap perlakuan, yaitu saat ratun berumur 3 hingga 17 hari jumlah individu lebih tinggi, dan saat ratun 31 hari hingga setelah dipanen jumlah individu terus menurun (Tabel 4). Jumlah individu laba-laba yang ditemukan di permukaan tanah paling banyak ditemukan pada perlakuan bioinsektisida cair (35\%), diikuti oleh kombinasi bioinsektisida cair dan kompos (34\%) sedangkan terendah ditemukan pada perlakuan kompos (31\%) (Gambar 2B).

Tabel 3. Karakteristik komunitas laba-laba yang ditemukan di tajuk padi yang diaplikasikan bioinsektisida cair, kompos cair, dan kombinasi bioinsektisida cair dan kompos cair

\begin{tabular}{lcccccccc}
\hline \multirow{2}{*}{ Karakteristik komunitas } & \multicolumn{7}{c}{ Umur ratun (hari) } \\
\cline { 2 - 9 } & 3 & 17 & 31 & 38 & 45 & 52 & 59 & $75^{*}$ \\
\hline Bioinsektisida cair & 6 & 7 & 5 & 5 & 6 & 4 & 5 & 4 \\
$\quad$ Jumlah spesies (spesies) & 16 & 58 & 23 & 22 & 27 & 12 & 11 & 21 \\
$\quad$ Jumlah individu (individu/60 ayunan) & 1,6 & 1,57 & 1,29 & 1,53 & 1,63 & 1,29 & 1,4 & 1,24 \\
$\quad$ Indeks keanekaragaman (H') & $1,6,38$ & 0,31 & 0,43 & 0,36 & 0,33 & 0,33 & 0,45 & 0,50 \\
$\quad$ Indeks dominasi (d) & 0,89 & 0,81 & 0,93 & 0,95 & 0,91 & 0,93 & 0,85 & 0,89 \\
Indeks kemerataan (E) & & & & & & & & \\
Kompos cair & 6 & 7 & 3 & 4 & 4 & 4 & 3 & 3 \\
$\quad$ Jumlah spesies (spesies) & 17 & 44 & 17 & 20 & 24 & 15 & 3 & 14 \\
Jumlah individu (individu/60 ayunan) & 1,6 & 1,64 & 1,21 & 1,58 & 1,2 & 1,19 & 1,1 & 0,98 \\
$\quad$ Indeks keanekaragaman (H') & 0,35 & 0,34 & 0,50 & 0,28 & 0,55 & 0,53 & 0,33 & 0,57 \\
Indeks dominasi (d) & 0,92 & 0,84 & 0,87 & 0,98 & 0,86 & 0,86 & 1,00 & 0,89 \\
Indeks kemerataan (E) & & & & & & & & \\
Bioinsektisida + kompos cair & 4 & 4 & 4 & 5 & 5 & 5 & 4 & 4 \\
$\quad$ Jumlah spesies (spesies) & 14 & 30 & 27 & 20 & 26 & 22 & 9 & 17 \\
Jumlah individu (individu/60 ayunan) & 1,4 & 1,3 & 1,5 & 1,73 & 1,43 & 1,42 & 1,4 & 1,22 \\
Indeks keanekaragaman (H') & 0,286 & 0,43 & 0,41 & 0,34 & 0,38 & 0,36 & 0,33 & 0,47 \\
Indeks dominasi (d) & 0,85 & 0,94 & 0,84 & 0,89 & 0,89 & 0,88 & 0,99 & 0,88 \\
$\quad$ Indeks kemerataan (E) & & & & & & &
\end{tabular}

*14 hari setelah padi ratun dipanen.

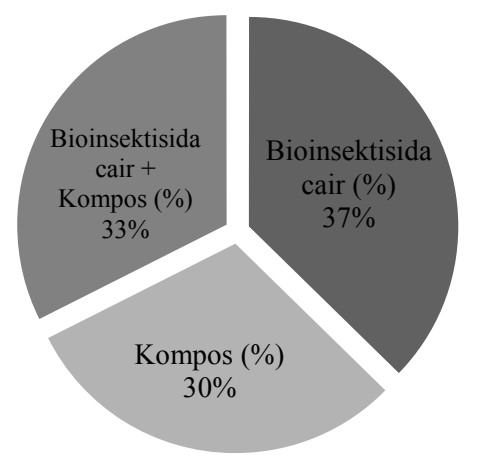

A

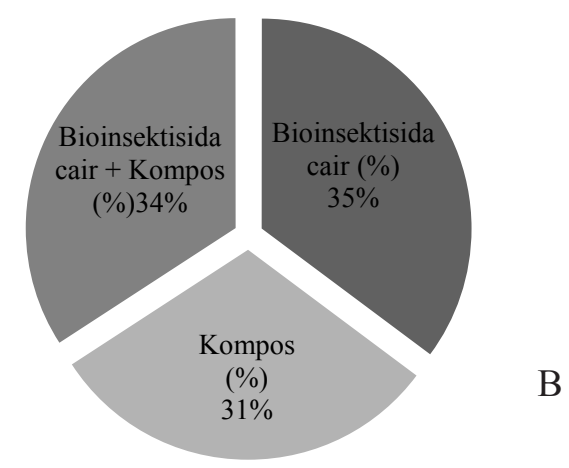

Gambar 2. Kelimpahan atau jumlah individu laba-laba pada tiga petak perlakuan bioinsektisida untuk penghuni tajuk (A); dan permukaan tanah (B). 
Tabel 4. Karakteristik komunitas laba-laba yang ditemukan di permukaan tanah di ekosistem padi yang diaplikasikan bioinsektisida cair, kompos cair, dan kombinasi bioinsektisida cair dan kompos cair

\begin{tabular}{lllllllll}
\hline \multirow{2}{*}{ Karakteristik komunitas } & \multicolumn{7}{c}{ Umur ratun (hari) } \\
\cline { 2 - 9 } & 3 & 17 & 31 & 38 & 45 & 52 & 59 & $75^{*}$ \\
\hline Bioinsektisida cair & 3 & 1 & 2 & 2 & 3 & 2 & 1 & 2 \\
$\quad$ Jumlah spesies (spesies) & 4 & 7 & 3 & 4 & 9 & 14 & 3 & 2 \\
$\quad$ Jumlah individu (individu/12 perangkap) & 1,04 & 0 & 0,64 & 0,56 & 0,85 & 0,6 & 0 & 0,69 \\
$\quad$ Indeks keanekaragaman (H') & 0,50 & 1 & 0,67 & 0,75 & 0,67 & 0,71 & 1 & 0,50 \\
$\quad$ Indeks dominasi (d) & 0,94 & 0 & 0,92 & 0,81 & 0,77 & 0,86 & 0 & 1,0 \\
$\quad$ Indeks kemerataan (E) & & & & & & & & \\
Kompos cair & 4 & 1 & 1 & 2 & 3 & 2 & 0 & 3 \\
$\quad$ Jumlah spesies (spesies) & 7 & 7 & 2 & 4 & 5 & 5 & 0 & 10 \\
Jumlah individu (individu/12 perangkap) & 1,28 & 0 & 0 & 0,56 & 1,05 & 0,67 & 0 & 0,94 \\
Indeks keanekaragaman (H') & 0,43 & 1 & 1 & 0,75 & 0,40 & 0,60 & 0 & 0,50 \\
Indeks dominasi (d) & 0,92 & 0 & 0 & 0,81 & 0,96 & 0,97 & 0 & 0,86 \\
$\quad$ Indeks kemerataan (E) & & & & & & & & \\
Bioinsektisida + Kompos cair & 4 & 1 & 2 & 3 & 1 & 1 & 1 & 3 \\
$\quad$ Jumlah spesies (spesies) & 6 & 13 & 5 & 5 & 6 & 6 & 1 & 5 \\
$\quad$ Jumlah individu (individu/12 perangkap) & 1,33 & 0 & 0,5 & 0,95 & 0 & 0 & 0 & 0,95 \\
Indeks keanekaragaman (H') & 0,33 & 1 & 0,80 & 0,60 & 1 & 1 & 1 & 0,60 \\
Indeks dominasi (d) & 0,96 & 0 & 0,72 & 0,86 & 0 & 0 & 0 & 0,68 \\
$\quad$ Indeks kemerataan (E) & & & & & & & & \\
\hline
\end{tabular}

*14 hari setelah padi ratun dipanen.

Tabel 5. Matriks kemiripan (indeks Sorensen) komunitas artropoda predator di ekosistem padi yang diaplikasikan bioinsektisida cair, kompos cair, dan kombinasi bioinsektisida cair dan kompos cair

\begin{tabular}{|c|c|c|c|c|}
\hline Habitat & Perlakuan & $\begin{array}{l}\text { Bioinsektisida } \\
\text { cair }\end{array}$ & Kompos & $\begin{array}{c}\text { Bioinsektisida cair } \\
+ \text { Kompos }\end{array}$ \\
\hline \multirow[t]{3}{*}{ Penghuni tajuk } & Bioinsektisida cair & 1 & 0,74 & 0,72 \\
\hline & Kompos & & 1 & 0,83 \\
\hline & Bioinsektisida cair + Kompos & & & 1 \\
\hline \multirow[t]{3}{*}{ Penghuni tanah } & Bioinsektisida cair & 1 & 0,77 & 0,71 \\
\hline & Kompos & & 1 & 0,77 \\
\hline & Bioinsektisida cair + Kompos & & & 1 \\
\hline
\end{tabular}

\section{PEMBAHASAN}

Hasil penelitian ini menunjukkan bahwa aplikasi bioinsektisida dari cendawan entomopatogen, $B$. bassiana tidak berdampak buruk terhadap jumlah spesies, kelimpahan, dan komposisi spesies labalaba penghuni tajuk. Terdapat kecenderungan bahwa kelimpahan laba-laba penghuni tajuk lebih tinggi pada petak yang diaplikasikan bioinsektisida cair dan kombinasi bioinsektisida cair dan kompos dibandingkan dengan yang tidak diaplikasi. Selain itu, kelimpahan laba-laba penghuni tajuk sebelum diaplikasikan bioinsektisida (umur ratun 3 hari) masih rendah, namun setelah diaplikasi bioinsekisida terjadi peningkatan kelimpahannya (umur ratun 17 hari). Hal ini menunjukkan bahwa, laba- laba tidak terganggu oleh adanya aplikasi bioinsektisida tersebut. Belum ditemukan hasil penelitian yang melaporkan bahwa B. bassiana dapat membunuh laba-laba.

Kelimpahan laba-laba baik penghuni tajuk maupun tanah lebih tinggi pada perlakuan bioinsektisida daripada tidak diaplikasi bioinsektisida. Hasil pengamatan langsung di lapangan petak yang diaplikasi bioinsektisida memiliki pertumbuhan ratun yang lebih subur dan jumlah anakan lebih banyak sehingga lebih rimbun dan lebih sesuai untuk habitat laba-laba. Suwandi et al. (2012) menyatakan kandungan ekstrak kompos kulit udang pada bioinsektisida di penelitian ini dapat meningkatkan secara signifikan jumlah anakan ratun. Hasil penelitian sebelumnya cenderung 
mengungkap peran B. bassiana dalam membunuh serangga hama, seperti walang sangit (Herlinda et al. 2008a), wereng (Herlinda et al. 2008b), kutudaun (Herlinda 2010; Herlinda et al. 2010), kutu putih pepaya (Herlinda et al. 2012), dan ulat kubis (Nunilahwati et al. 2012).

Pada penelitian ini, insektisida sintetik tidak diaplikasikan di pertanaman padi ratun. Pertanaman padi ratun diaplikasikan bioinsektisida dengan bahan aktif $B$. bassiana dan bahan pembawa kompos cair sedangkan petak kontrol hanya diaplikasikan kompos cair. Dengan demikian, kompos cair tersebut dapat ditemukan baik di petak perlakuan maupun petak kontrol. Zi-yang et al. (2011) menyatakan aplikasi bahan organik di ekosistem sawah sangat menguntungkan komunitas laba-laba dan serangga predator, yakni kelimpahan dan keanekaragaman spesies lebih tinggi pada lahan yang diaplikasi dengan pupuk organik dibandingkan dengan lahan konvensional yang menggunakan bahan sintetik. Fenomena yang sama juga dilaporkan Herlinda et al. (2008c) yang menyatakan aplikasi bioinsektisida tidak mempengaruhi kelimpahan dan keanekaragaman spesies serangga predator hama padi.

Pada tiga petak perlakuan, saat awal tanam padi ratun (umur ratun 3 dan 17 hari) cenderung kelimpahan dan keanekaragaman spesies laba-laba penghuni tajuk lebih tinggi dibandingkan dengan padi ratun yang semakin tua. Bila dikaitkan dengan mangsa utamanya dari kelompok wereng cenderung lebih tinggi saat awal pertumbuhan padi. Widiarta et al. (2006) menyatakan bahwa kelimpahan laba-laba mengikuti peningkatan populasi mangsa utamanya. Populasi wereng mulai meningkat pada awal musim tanam padi dan cenderung lebih tinggi pada padi fase vegetatif (Arofah et al. 2013). Mahrub (1999) menyatakan lebih tingginya kelimpahan dan keanekaragaman artropoda predator pada padi fase yang muda karena habitat lebih sesuai dan banyak menyediakan lebih banyak mangsa.

Fenomena yang sama terjadi pada laba-laba penghuni permukaan tanah, yaitu aplikasi bioinsektisida $B$. bassiana tidak berdampak terhadap jumlah spesies, kelimpahan, dan keanekaragaman spesies laba-laba penghuni tanah tersebut. Kelimpahan laba-laba penghuni tanah cenderung tidak menunjukkan perbedaan antara yang diaplikasikan bioinsektisida dengan tanpa bioinsektisida. Hasil penelitian ini menunjukkan bahwa bioinsektisida tidak menurunkan kelimpahan maupun jumlah spesies laba-laba penghuni permukaan tanah.

Kelimpahan laba-laba penghuni permukaan tanah cenderung lebih tinggi pada awal pertumbuhan ratun dibandingkan dengan padi ratun yang semakin tua. Fenomena yang sama terjadi juga pada laba-laba penghuni tajuk. Hal ini disebabkan famili laba-laba yang dominan ditemukan baik pada tajuk maupun permukaan tanah adalah Lycosidae, sedangkan Lycosidae sendiri merupakan pemangsa wereng. Kelimpahan Lycosidae atau pemangsa wereng cenderung akan mengikuti perubahan populasi mangsanya atau wereng (Munyuli 2009).

Total semua spesies laba-laba penghuni tajuk padi ratun yang ditemukan pada ketiga petak perlakuan adalah 18 spesies, sedangkan pada permukaan tanah hanya ditemukan 8 spesies. Begitujuga dengan kelimpahan, ada kecenderungan laba-laba penghuni tajuk lebih banyak ditemukan dibandingkan laba-laba di permukaan tanah. Lebih banyaknya jumlah spesies dan kelimpahan labalaba penghuni tajuk dibandingkan dengan yang ditemukan di permukaan tanah menunjukkan aktivitas laba-laba banyak terjadi di tajuk. Hal ini disebabkan laba-laba mencari mangsa di tajuk padi sedangkan aktivitas di permukaan tanah terjadi lebih bersifat karena aktivitas penyebaran atau perpindahan laba-laba dari satu habitat ke habitat lainnya. Widiarta et al. (2006) menyatakan labalaba akan mengumpul pada habitat yang banyak mangsanya. Mangsa tersebut antara lain wereng, penggerek batang padi, dan kepik yang ada di tajuk tanaman (Arofah et al. 2013).

Dari lima famili yang ditemukan pada tajuk padi ratun di pasang surut ini, yaitu Lycosidae, Araneidae, Tetragnathidae, Oxyopidae, dan Clubionidae, hanya Lycosidae dan Clubionidae yang merupakan labalaba pemburu, sisanya merupakan laba-laba pembuat jaring. Pada penelitian ini, di sawah pasang surut tidak ditemukan famili Linyphiidae karena habitat di sana lebih kering sehingga kurang sesuai untuk habitat laba-laba tersebut. Schmidt \& Tscharntke (2005) menyatakan Linyphiidae lebih menyukai habitat yang lembab. Famili labalaba yang ditemukan di permukaan tanah adalah Lycosidae, Araneidae, dan Theridiidae. Hasil penelitian ini menunjukkan bahwa famili Araneidae dan Theridiidae yang merupakan laba-laba pem- 
buat jaring dapat ditemukan di permukaan tanah. Hal ini dapat terjadi karena laba-laba tersebut saat ditemukan masih pradewasa yang memiliki kemampuan menghasilkan bola kecil mirip balon yang mudah diterbangkan angin sehingga dapat terperangkap dalam perangkap lubang yang dipasang di permukaan tanah.

\section{KESIMPULAN}

Dari hasil penelitian ini dapat disimpulkan bahwa aplikasi bioinsektisida $B$. bassiana tidak mempengaruhi kelimpahan dan kekayaan spesies laba-laba penghuni tajuk. Selain itu, kekayaan spesies dan kelimpahan laba-laba penghuni permukaan tanah cenderung tidak berbeda antara petak yang diaplikasi dan tidak diaplikasi bioinsektisida. Dari analisis kemiripan komposisi spesies labalaba disimpulkan bahwa aplikasi bioinsektisida juga tidak mempengaruhi komposisi spesies labalaba. Dengan demikian, aplikasi bioinsektisida B. bassiana tidak membahayakan laba-laba, baik penghuni tajuk maupun tanah di ekosistem padi ratun.

\section{UCAPAN TERIMA KASIH}

Penelitian ini bagian dari Penelitian Hibah Kompetensi yang dibiayai oleh Direktorat Jenderal Pendidikan Tinggi, Kementerian Pendidikan dan Kebudayaan, sesuai dengan Surat Perjanjian Penugasan dalam Rangka Pelaksanaan Program Penelitian Hibah Kompetensi Tahun Anggaran 2013, Nomor: 093.a/UN9.3.1/PL/2013, tanggal 13 Mei 2013 yang diketua oleh Siti Herlinda. Ucapan terima kasih kepada Dr. Chandra Irsan atas bantuan identifikasi spesies laba-laba.

\section{DAFTAR PUSTAKA}

Arofah S, Trisnawati I, Tjahjaningrum D. 2013. Pengaruh habitat termodifikasi menggunakan serai terhadap serangga herbivora dan produktivitas padi varietas IR-64 di Desa Purwosari, Pasuruan. Jurnal Sains dan Seni Pomits 2:2337-3520.
Barrion AT, Litsinger JA. 1995. Riceland Spiders of South and Southeast Asia. Manila: International Rice Research Institute.

Herlinda S. 2010. Spore density and viability of entomopathogenic fungal isolates from Indonesia, and its virulence against Aphis gossypii Glover (Homoptera: Aphididae). Tropical Life Sciences Research 21:13-21.

Herlinda S, Darmawan KA, Firmansyah, Adam T, Irsan C, Thalib R. 2012. Bioesai bioinsektisida Beauveria bassiana dari Sumatera Selatan terhadap kutu putih pepaya (Paracoccus marginatus). Jurnal Entomologi Indonesia 9:8187. doi: http://dx.doi.org/10.5994/jei.9.2.81.

Herlinda S, Irsan C, Mayasari R, Septariani S. 2010. Identification and selection of entomopathogenic fungi as biocontrol agents for Aphis gossypii from South Sumatra. Microbiology Indonesia 4:137-142. doi: http://dx.doi.org/10.5454/mi.4.3.7.

Herlinda S, Mulyati SI, Suwandi. 2008a. Selection of isolates of entomopathogenic fungi, and the bioefficacy of their liquid production against Leptocorisa oratorius Fabricius nymphs. Microbiology Indonesia 2:141-145. doi: http:// dx.doi.org/10.5454/mi.2.2.9.

Herlinda S, Mulyati SI, Suwandi. 2008b. Jamur entomopatogen untuk mengendalikan wereng coklat pada tanaman padi. Agritrop 27:119-126.

Herlinda S, Waluyo, Estuningsih SP, Irsan C. 2008c. Perbandingan keanekaragaman spesies dan kelimpahan arthropoda predator penghuni tanah di sawah lebak yang diaplikasi dan tanpa aplikasi insektisida. Jurnal Entomologi Indonesia 5:96107.

Herlinda S, Rauf A, Sosromarsono S, Kartosuwondo U, Siswadi, Hidayat P. 2004. Artropoda musuh alami penghuni ekosistem persawahan di daerah Cianjur, Jawa Barat. Jurnal Entomologi Indonesia 1:9-15.

Khodijah, Herlinda S, Irsan C, Pujiastuti Y, Thalib R. 2012. Artropoda predator penghuni ekosistem persawahan lebak dan pasang surut Sumatera Selatan. Jurnal Lahan Suboptimal 1:57-63.

Ludwig SW, Oetting RD. 2001. Susceptibility of natural enemies to infection by Beauveria bassiana and impact of insecticides on Ipheseius degenerans (Acari: Phytoseiidae). Journal of Agricultural and Urban Entomology 18:169178.

Magurran AE. 1987. Ecological Diversity and Its Measurement. New Jersey: Princeton University Press.

Mahrub E. 1999. Kajian keanekaragaman artropoda pada lahan padi sawah tanpa pestisida dan 
manfaatnya dalam pengendalian hama terpadu. Jurnal Perlindungan Tanaman Indonesia 5:3541.

Munyuli T. 2009. Is Pardosa pseudoannulata an effective predator agent of Aphis craccivora in Uganda and in Democratic Republic of Congo? Tunisian Journal of Plant Protection 4:91-98.

Nunilahwati H, Herlinda S, Irsan C, Pujiastuti Y. 2012. Eksplorasi, isolasi, dan seleksi jamur entomopatogen Plutella xylostella (Lepidoptera: Yponomeutidae) pada tanaman caisin (Brassica chinensis) di Sumatera Selatan. Jurnal HPT Tropika 12:1-11.

Schmidt MH, Tscharntke T. 2005. Landscape context of sheetweb spider (Araneae: Linyphiidae) abundance in cereal fields. Journal of Biogeography 32:467-473. doi: http://dx.doi. org/10.1111/j.1365-2699.2004.01244.x.

Shepard BM, Barrion AT, Litsinger JA. 1991. Friends of the Rice Farmer: Helpful Insects, Spiders, and Pathogens. Manila: International Rice Research Institute.

Suwandi. 2004. Effectiveness of shrimps shell compost extract for suppression of leaf diseases on cowpea, chili pepper and cabbage. Pest Tropical Journal 1:18-25.

Suwandi, Ammar M, Irsan C. 2012. Aplikasi Ekstrak kompos meningkatkan hasil dan menekan penyakit padi sistem ratun di sawah pasang surut Kabupaten Banyuasin. Jurnal Lahan Suboptimal 1:116-122.

Thalib R, Fernando R, Khodijah, Meidalima D, Herlinda S. 2013. Patogenesitas isolat Beauveria bassiana dan Metarhizium anisopliae asal tanah lebak dan pasang surut Sumatera Selatan untuk agens hayati Scirpophaga incertulas. Jurnal HPT Tropika 13:10-18.

Thungrabeab M, Tongma S. 2007. Effect of entomopathogenic fungi, Beauveria bassiana (Balsam) and Metarhizium anisopliae (Metsch) on non target insects. KMITL Science and Technology 7:8-12.

Widiarta IN, Kusdiaman D, Suprihanto. 2006. Keragaman arthropoda pada padi sawah dengan pengelolaan tanaman terpadu. Jurnal HPT Tropika 6:61-69.

Zhu H, Lou XM, Song JX, Fan MZ, Li ZZ. 2011. Effects of Beauveria bassiana on Myzus persicae and its two predaceous natural enemies. Ying Yong Sheng Tai Xue Bao 22:2413-2418.

Zi-yang Z, Xian-cai H, Ling M, Tongzhou X, Baoping L. 2011. Arthropod diversity on plants at field margins of organic farming paddy rice. Chinese Journal of Ecology 30:1347-1353. 